\section{Potential Economic Impacts from Offshore Wind in the Great Lakes Region}

Offshore wind is a clean, renewable source of energy and can be an economic driver in the United States. To better understand the employment opportunities and other potential regional economic impacts from offshore wind development, the U.S. Department of Energy (DOE) funded research that focuses on four regions of the country. The studies use multiple scenarios with various local job and domestic manufacturing content assumptions. Each regional study uses the new offshore wind Jobs and Economic Development Impacts (JEDI) model, developed by DOE's National Renewable Energy Laboratory. ${ }^{1}$ This fact sheet summarizes the potential economic impacts identified by the study for the Great Lakes region.

\section{JEDI Models}

The JEDI models are spreadsheet-based tools that estimate the economic impacts of constructing and operating power plants, fuel-production facilities, and other projects at the local level. JEDI results are intended to be estimates, not precise predictions. Based on user-entered, project-specific data or default inputs (derived from industry norms), JEDI models estimate the number of jobs and other economic impacts to a local area (in this case, the Great Lakes region) that can reasonably be supported by a new power plant, like an offshore wind facility. The JEDI models estimate gross impacts (as opposed to net) and are not a measure of project profitability or viability. JEDI presents jobs, earnings, and regional economic output results, which are distributed across three categories:

- Project Development and Onsite Labor Impacts

- Local Revenue and Supply Chain Impacts

- Induced Impacts.

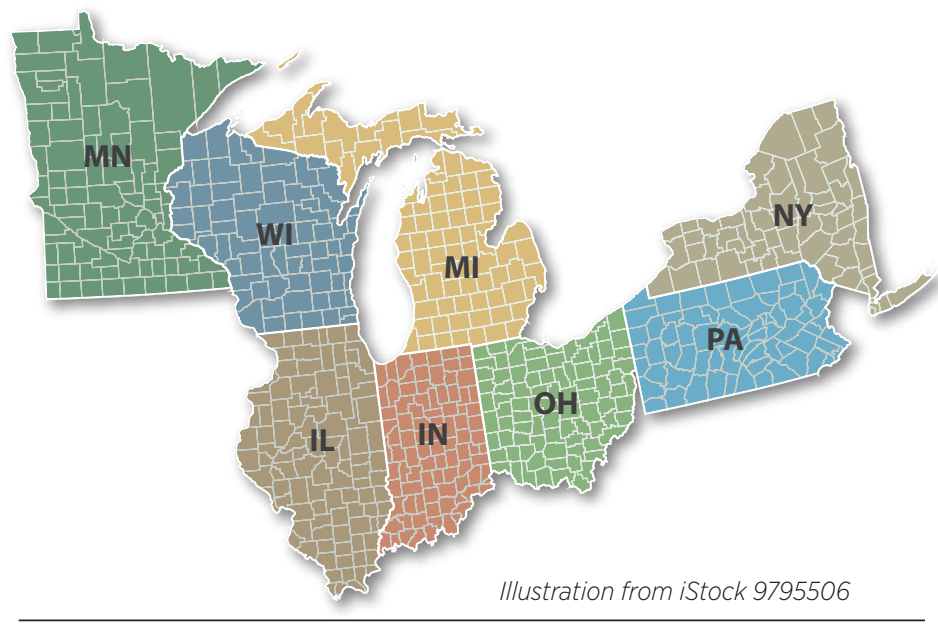

${ }^{1}$ The model can be downloaded free of charge at www.nrel.gov/analysis/jedi.

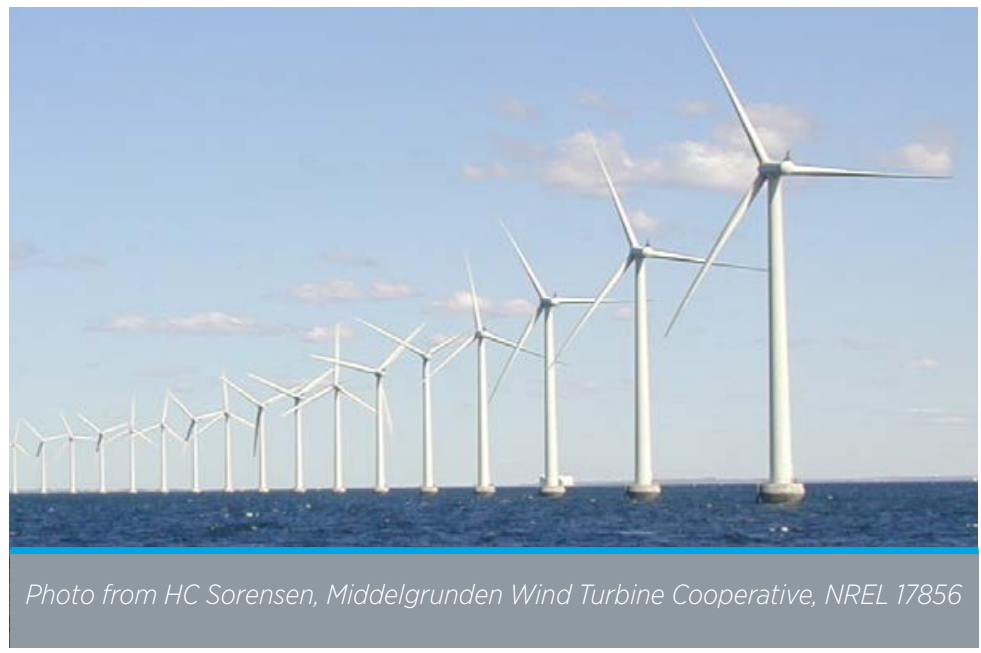

Economic multipliers contained within the model are derived from Minnesota IMPLAN Group's IMPLAN accounting software and state data files. Sources include the Bureau of Labor Statistics, Bureau of Economic Analysis, and the U.S. Census. Jobs are measured and reported as full-time equivalents (FTEs). One FTE is equivalent to one full-time worker who is employed for 1 year; part-time and seasonal workers are a fraction of an FTE. The results of each offshore wind power scenario represent an estimate of the number of supply chain, construction, and operations and maintenance $(\mathrm{O} \& \mathrm{M})$ jobs that could be supported in the Great Lakes region (Figure 1).

\section{The Great Lakes Region}

The Great Lakes region is defined in this analysis as all U.S. states that touch Lakes Superior, Michigan, Huron, Erie, and Ontario: Illinois, Indiana, Michigan, Minnesota, New York, Ohio, Pennsylvania, and Wisconsin.

Offshore wind development and operation in the Great Lakes differs from similar activities in the ocean. Accessibility of Great Lakes installations can be limited by locks, port facilities, and fresh water that freezes in the winter. There is less wear and tear on offshore wind components in the Great Lakes because fresh water is less corrosive than salt water, and water levels do not change as frequently and considerably as do tidal waters. The water depth in the Great Lakes is also highly variable, both within lakes and from lake to lake. Most potential sites in shallow water are located in Lakes Erie and Ontario.

Jobs supported by offshore wind are well compensated, with average annual earnings (including benefits) of $\$ 140,000$ annually. Supply chain job holders are estimated to earn approximately $\$ 70,000$, and earnings from induced jobs are approximately $\$ 50,000$.

This study considered three offshore wind development scenarios examining different levels of capacity installed, regional supply chain development, and construction and operation costs. Development scenarios were crafted using insight from regional renewable energy experts. Offshore wind 
installations range from a low of 250 megawatts (MW) by 2020 to a high of 5,000 MW by 2030 (Table 1).

Investment in manufacturing and other important industries in the offshore wind supply chain within the Great Lakes region would be needed before many of the materials needed to construct and operate an offshore wind plant could be produced in the area. This investment could be proportionate to offshore wind deployment in the region. Similarly, greater development of a local offshore wind supply chain would likely put downward pressure on costs due to economies of scale and reduced transportation costs. Some services (i.e., engineering, business to business, fabrication, and maritime) could be obtained locally without significant investment.

Table 1. Scenarios Modeled (2020 Value / 2030 Value) for Offshore Wind in the Great Lakes Region

\begin{tabular}{|l|l|l|l|}
\hline \multicolumn{4}{|c|}{ Results in Years 2020/2030 } \\
\hline Scenario & $\begin{array}{l}\text { Cumulative } \\
\text { Capacity } \\
\text { Installed (MW) }\end{array}$ & $\begin{array}{l}\text { Supply Chain } \\
\text { Investment } \\
\text { (Local Content) }\end{array}$ & $\begin{array}{l}\text { Construction } \\
\text { Cost } \\
(\$ / \mathrm{kW})\end{array}$ \\
\hline Low deployment & $250 / 1,000$ & $12 \% / 23 \%$ & $\$ 6,632 / \$ 5,969$ \\
\hline $\begin{array}{l}\text { Moderate } \\
\text { deployment }\end{array}$ & $500 / 2,000$ & $15 \% / 43 \%$ & $\$ 6,632 / \$ 5,306$ \\
\hline High deployment & $1,000 / 5,000$ & $30 \% / 56 \%$ & $\$ 6,632 / \$ 4,642$ \\
\hline
\end{tabular}

Table 2 shows further detail about local content assumptions for major construction expenditures. Only 2030 values are shownall local content values for the expenditure categories listed are zero in 2020. All scenarios assume that all O\&M staff except for managers will be residents of the Great Lakes region. The moderate and high scenarios assume that all construction and O\&M managers will be residents of the region by 2030, while the low scenario assumes half will be local.

Table 2. 2030 Local Content of Select Expenditures

\begin{tabular}{|c|c|c|c|c|}
\hline & $\begin{array}{l}\text { Blades } \\
\text { and } \\
\text { Towers }\end{array}$ & $\begin{array}{l}\text { Nacelles, } \\
\text { Substructure, } \\
\text { Foundation }\end{array}$ & $\begin{array}{l}\text { Erection } \\
\text { Installation } \\
\text { Services }\end{array}$ & $\begin{array}{l}\text { Converter } \\
\text { and } \\
\text { Substation }\end{array}$ \\
\hline $\begin{array}{l}\text { Low } \\
\text { deployment }\end{array}$ & $0 \%$ & $0 \%$ & $25 \%$ & $0 \%$ \\
\hline $\begin{array}{l}\text { Moderate } \\
\text { deployment }\end{array}$ & $50 \%$ & $50 \%$ & $50 \%$ & $25 \%$ \\
\hline $\begin{array}{l}\text { High } \\
\text { deployment }\end{array}$ & $75 \%$ & $75 \%$ & $75 \%$ & $50 \%$ \\
\hline
\end{tabular}

A scenario's economic impact will depend on the level of development and portion of expenditures made within the Great Lakes region. In the moderate scenario, development is estimated to support approximately 1,220 total FTE jobs in 2020 and an average of approximately 2,350 annually through 2030 . The portion of onsite jobs is estimated to increase from $17 \%$ in 2020 to $21 \%$ in 2030 , while local revenue and supply chain jobs decrease from $42 \%$ in 2020 to $40 \%$ in 2030 .

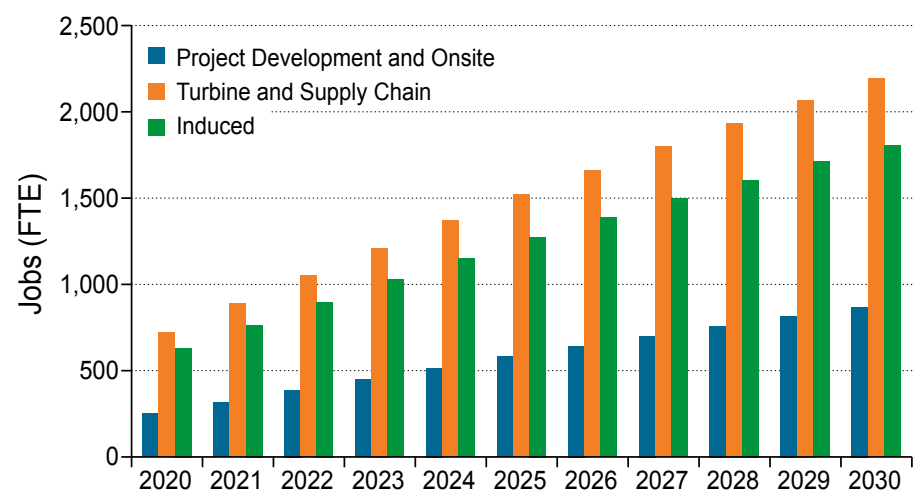

Figure 1. Estimated number of jobs supported by offshore wind deployment from 2020 to 2030 in the Great Lakes region (moderate scenario)

Table 3: Jobs Supported by the Moderate Offshore Wind Scenario for the Great Lakes Region

\begin{tabular}{|c|c|c|}
\hline & $\begin{array}{r}\text { Jobs (FTE) } \\
2020\end{array}$ & $\begin{array}{r}\text { Jobs (FTE) } \\
2030\end{array}$ \\
\hline \multicolumn{3}{|l|}{ During Construction Period } \\
\hline $\begin{array}{l}\text { Project Development and } \\
\text { Onsite Impacts }\end{array}$ & 210 & 700 \\
\hline $\begin{array}{l}\text { Construction and } \\
\text { Interconnection Labor }\end{array}$ & 120 & 620 \\
\hline Construction-Related Services & 90 & 80 \\
\hline Turbine and Supply Chain Impacts & 510 & 1,340 \\
\hline Induced Impacts & 500 & 1,270 \\
\hline Total Impacts during Construction & 1,220 & 3,310 \\
\hline \multicolumn{3}{|l|}{ During Operating Years (Annual) } \\
\hline Onsite Labor Impacts & 30 & 170 \\
\hline $\begin{array}{l}\text { Local Revenue and Supply } \\
\text { Chain Impacts }\end{array}$ & 210 & 850 \\
\hline Induced Impacts & 130 & 530 \\
\hline Total Impacts during O\&M & 370 & 1,550 \\
\hline
\end{tabular}

Totals may not sum due to rounding.

DOE's Wind \& Water Power Technologies Office funded the Great Lakes Wind Collaborative and the National Renewable Energy Laboratory to perform this work under Contract No. DE-AC36-08GO28308.

For more information on DOE offshore wind work, please visit Offshore Wind Market Acceleration Projects at www.eere.energy.gov/wind/offshore_market_acceleration.html. Renewable Energy
For more information, visit: wind.energy.gov 